women had gender reassignment surgery, the only known example of such operations being performed in military hospitals. ${ }^{10}{ }^{11}$ They were given new identity documents, discharged from the military, and told to cut themselves off from family and friends.

The casualty rates were high. Patients died during surgery, and some were discharged before reassignment was completed, with extra surgery required. Preoperative or postoperative assessment was not done, informed consent was not obtained, and expensive hormone regimens were needed to maintain appearance. Patients later petitioned the military for compensation to pay for hormones or surgery.

The rationale for giving homosexuals reassignment surgery, in complete ignorance of the scientific literature on transsexualism, can only be described as repulsive. It was based on the simplistic belief that male homosexuals were sissies, female homosexuals were tomboys, and surgery would end their preference for the same sex by allowing them to fulfil their projected role in the opposite sex. The only conclusion that can be reached is that the psychiatrists involved were not only woefully and balefully ignorant but functioned as an extension of the military ethos.

Rumours of these activities circulated for years, ${ }^{12}$ but details of the programme first came to light at hearings of the Truth and Reconciliation Commission with submission of The Aversion Project, a detailed investigation of treatment of homosexuals in the South African Defence Force by a coalition of groups, including the Medical Research Council. ${ }^{13}$

In 1995, the Medical Association of South Africa issued a public apology for past wrongdoings. ${ }^{14}$ The South African Society of Psychiatrists does not concede that major abuses were perpetuated from within its ranks. ${ }^{15}$ Until there is a full and open investigation of medical abuses in the South African Defence Force, psychiatry in South Africa will remain compromised. To maintain credibility, offenders must be brought to justice and a regulatory system established to ensure such atrocities do not occur again. Anything less will be a serious injustice.

Robert M Kaplan forensic psychiatrist

Liaison Clinic, 310 Crown Street, Wollongong, New South Wales 2500, Australia

(liaison3@bigpond.com)

Competing interests: None declared.

1 Gay P. Freud, a life in our time. London: Pan Macmillan 1989.

2 Lifton RJ. The Nazi doctors:medical killing and the psychology of genocide. New York: Basic Books, 1986

Lifton RJ. Doctors and torture. N Engl J Med 2004;351:415-6.

4 Human Rights Commission Fact Paper FP7. Deaths in detention. Braamfontein, August 1990.

Silove D. Doctors and the state: lessons from the Biko case. Soc Sci Med Silove D. Doctors
1990;30:417-29.

1990;30:417-29.
Kaplan R. The aversion project-psychiatric abuses in the South African defence force during the apartheid era. $S$ Afr Med J 2001;90:216-7.

Smith G, Bartlett A, King M. Treatments of homosexuality in Britain since the 1950s - an oral history: the experience of patients. BMJ 2004;328:427.

8 King M, Smith G, Bartlett A. Treatments of homosexuality in Britain since the $1950 \mathrm{~s}-$ an oral history: the experience of professionals. BMJ 2004;328:429

9 Obituary.Judd Marmor. BMJ 2004;328:466.

10 Kirk Paul. Mutilation by the military (and related articles). Mail \& G Guardian, August 4-August 10, 2000. www.geocities.com/crosswix/index.html (accessed 10 Dec 2004)

11 Bell T. Unfinished business: South Africa, apartheid and truth. New York: Verso, 2003.

12 Sher A. Beside myself. London: Arrow, 2002.

13 Van Zyl M, de Gruchy J, Lapinsky S, Lewin S, Reid G. The aversion project: human rights abuses of gays and lesbians in the SADF by health workers during the apartheid era. Cape Town: Simply Said and Done on behalf of Gay and Lesbian Archives Health and Human Rights Project, Medical Research Council, National Coalition for Gay and Lesbian Equality, 1999.

14 Van der Linde I. Sometimes having to say you're sorry. S Afr Med J 1995:85:715-6.

15 Gillis LS, Nash ES. Psychiatry under scrutiny-the Society of Psychiatrists in the apartheid years. S Afr J Psychiatry 2002;8:7-11.

\title{
Climate change and risk to health
}

\section{The risk is complex, and more than a sum of risks due to individual climatic factors}

$\mathrm{L}$ ast century was the warmest for 1800 years. Earth's average surface temperature apparently is now higher than for the previous 100000 years. Combinations of long cycle variations in orbital and planetary motion cause changes in the world's climate, as do shorter term irregular variations in solar activity and vulcanism. Extraordinarily, the human enterprise is now so large that we are imposing extra "forcing" on the climate system, via emission of greenhouse gases. ${ }^{12}$

The anticipated change in climate (average global warming of around $2-3^{\circ} \mathrm{C}$ by 2100 ) would be extremely rapid in geological terms ${ }^{12}$-and much faster than the environmentally disruptive warming that began around 15000 years ago, after the last ice age. If we cannot reduce our escalating emission of greenhouse gases radically in the next few decades, climate change will continue for centuries and the oceans will rise for millennia. ${ }^{1}$ Inevitably this would further heighten the risks to population health and survival.

Feedback processes and surprise climate events could amplify these risks greatly. ${ }^{3}$ Advances in climate science and modelled forecasting show that climate change will entail more than linear trends. As the climate system gains energy its variability will increase. Heatwaves, cyclones, floods, and the El Niño cycle will tend to become more frequent and intense. Further, palaeoclimatic evidence, such as that from ice cores and corals, shows that Earth's biogeophysical systems are prone to non-linear and even abrupt changessuch as the collapse of a grounded polar ice sheet and the rapid rise in sea level that then follows.

Research over the past decade has helped clarify the current and future risks to health from climate change. This understanding is incomplete, often uncertain, and sometimes contentious. We are most confident about the direct risks posed by heatwaves (think of the 15000 extra deaths in France in August 2003), cyclones, floods, and increasing air pollution. We expect that biotic systems that are sensitive to climatesuch as bacteria (like salmonella), the complex of vector, pathogen, and host that affects transmission of infection, the production of aeroallergens, and the agro-ecosystems that generate food-will be affected. Some evidence indicates that recent changes in the occurrence of infectious diseases in some locations (tickborne encephalitis in Sweden, cholera outbreaks 
in Bangladesh, malaria in the east African highlands) may in part reflect regional climatic changes. ${ }^{4-6}$

Climate change is not merely another addition to the list of environmental health hazards each warranting separate epidemiological study and risk management. It is a complex global environmental hazard, with knock-on effects, and is unlike exposure to a dose of some specific toxic chemical or radiation. Hence the overall risk to health is more than the aggregation of itemised disease risks due to particular climatic factors.

Widely evident, climate induced changes to physical and non-human biotic systems-such as glacial melt and altered seasonal timing of flowering, breeding, and migrating ${ }^{7}$ - provide insight into how biogeophysical systems can become uncoupled and dysfunctional. In similar fashion, the complex array of consequences of climate change, often perturbing social systems, can have impacts on health that are not well captured by itemised tallying. Unabated climate change would impair regional food and water supplies and thereby disrupt social and economic conditionsparticularly in already poor and vulnerable populations. Conflicts would arise, migrant flows would increase, and a mix of violence, injury, infectious diseases, malnutrition, mental disorders, and other health problems would result.

The relation between climate change and health is also distinctive in signifying that collectively we are on a non-sustainable path. Viewed anthropocentrically, sustainable development is about improving the quality of human life while maintaining Earth's life supporting biogeophysical systems and ecological processes. Our unprecedented impacts on the planet's climate system, ecosystems, biodiversity stocks, fresh water supplies, and other systems indicate that we are now eroding natural capital globally. ${ }^{9}$

Recent advances in understanding climate change and its impacts highlight the need for extraordinary and rapid reductions in emissions of carbon dioxide. Russia's recent decision to ratify (and thus activate) the Kyoto protocol is heartening but insufficient. More developed countries must adopt Britain's commitment to stepwise halving of national emissions by 2050 . The technical knowledge required to meet world energy needs, while radically reducing greenhouse emissions, already exists. ${ }^{10}$ However, both biosphere and human society are complex dynamic systems, and climate change therefore cannot be remedied by a single intervention. We need a multifaceted approach that encompasses decreased waste generating consumerism, improved energy efficiency, reduced deforestation, and greater use of non-fossil fuels.

As our understanding of the biosphere and climate system grows, we see that the main issues are not about such things as fine tuning the economic modelling of future emission trajectories, or noting the palaeoevidence that Earth's climate is ever changeable. The real challenge is to understand the complexity and uncertainties of changes in Earth's natural systems, the likely human impacts (and adaptive strategies to lessen those impacts) and the fundamental significance of human induced climate change in relation to the great task of achieving a sustainable way of living.

\section{Anthony McMichael director}

Rosalie Woodruff postdoctoral fellow

National Centre for Epidemiology and Population Health, Australian National University, Canberra, ACT 0200, Australia

(tony.mcmichael@anu.edu.au)

Competing interests: None declared.

1 Houghton JT, Ding Y, Griggs DJ, Noguer M, Linden PJ, Dai X, et al. Climate change 2001: the scientific basis. Contribution of Working Group I to the Third Assessment Report of the International Panel on Climate Change. Cambridge: Cambridge University Press, 2001.

2 Karl TR, Trenberth KE. Modern global climate change. Science 2003;302:1719-23.

Patz J. Global warming-health impacts may be abrupt as well as long term BMJ 2004:328:1269-70.

4 McMichael AJ, Campbell-Lendrum D, Ebi K, Githeko A, Scheraga J Woodward A, editors. Climate change and human health:risks and responses. Woodward A, editors. Climate change and hu
Geneva: World Health Organization, 2003.

5 Hales S, Woodward A. Climate change will increase demands on malaria control in Africa. Lancet 2003;362:1775.

6 Reiter P, Thomas CJ, Atkinson PM, Hay SI, Randolph SE, Rogers DJ, et al Global warming and malaria: a call for accuracy. Lancet Infect Dis 2004;4:323-24

7 Root TL, Price JT, Hall KR, Schneider SH, Rosenzweig C, Pounds JA. Fingerprints of global warming on wild animals and plants. Nature 2003;421:57-60.

8 Parmesan C, Yohe G. A globally coherent fingerprint of climate change impacts across natural systems. Nature 2003;421:37-42.

Wackernagel M, Schulz NB, Deumling D, Linares AC, Jenkins M, Kapos V, Wackernagel M, Schulz NB, Deumling D, Linares AC, Jenkins M, Kapos V,
et al. Tracking the ecological overshoot of the human economy. Proc Natl Acad Sci 2002;99:9266-71

10 Pacala S, Socolow R. Stabilization wedges: solving the climate problem for the next 50 years with current technologies. Science 2004;305:968-72

\section{Getting well from water}

\section{Bottled water exploits our worries about what affects health in the modern world}

W

ater is now everywhere. It has become a modern fashion and health accessory, as ubiquitous as the mobile phone. Students have a bottle in their bags or in front of them during lectures, people are jogging with water, and office workers have a bottle within easy reach of their desk. The rise of water as a health product is underpinned by people's worries about modern life. Bottled water is seen as a natural antidote to what the consumer sees wrong with modernity and bad for their healthchemicals and technologies full of risk and hazard, genetically engineered food, low level radiation, harmful medications, and sinister viruses. ${ }^{1}$
Sales figures confirm that bottled water is the world's fastest selling drink. In the United Kingdom, consumers spent $£ 1$ bn ( $\$ 1.9 \mathrm{bn} ; € 1.4 \mathrm{bn})$ on bottled water last year, a 70-fold increase from 20 years ago. In the United States, consumption of bottled water has risen from 2.5bn gallons (9.5bn litres) in 1992 to almost 6 bn gallons in 2002. Advertisers conjure up a thousand variations on the same theme- the theme of pure, clean, fresh, and unspoiled water. Drinking "pure" water restores energy and ensures health. Samuel Hahneman, the inventor of homoeopathy, knew this well. His product was also nothing but the purest of pure water, in which the deliberately added substances had been diluted away beyond 